\title{
Factor analysis of the geochemical associations in the Plavica ore deposit, Republic of North Macedonia
}

\section{Факторен анализ на геохимичните асоциации в находище Плавица, Република Северна Македония}

\author{
Kamen Popov, Kalin Ruskov, Gotse Zlatkov \\ Камен Попов, Калин Русков, Гоце Златков
}

University of Mining and Geology St. Ivan Rilski, Sofia 1700, Bulgaria. E-mail: kpopov@mgu.bg

\begin{abstract}
The aim of this study is to investigate the geochemical associations in the Plavica deposit in Republic of North Macedonia. The analyses of drill core samples from the detail exploration works were statistically processed to determine the groups of chemical elements with common spatial distributions. The resulting geochemical groups represent different stages of the ore forming hydrothermal processes. The main ore elements are represented by geochemical association of ([As, $\mathrm{Sb}, \mathrm{Au}, \mathrm{Sn}] \mathrm{Cu}, \mathrm{Bi}, \mathrm{Fe}, \mathrm{Ag}$ ) which group outlines the ore bodies.
\end{abstract}

Keywords: Plavica ore deposit, geochemical associations, 3D modelling, multidimensional statistics, factor analysis.

\section{Introduction}

The Plavica gold deposit is located in the Zletovo ore field of the Kratovo-Zletovo volcanic area in the Republic of North Macedonia. The KratovoZletovo ore district covers Kratovo-Zletovo volcanic complex with an area of about $1200 \mathrm{~km}^{2}$. The district is characterized by vein type $\mathrm{Pb}-\mathrm{Zn}$ mineralizations (as Zletovo and Blizanci deposits) and stockwork $\mathrm{Cu}-\mathrm{Au}$ disseminated mineralizations (as Borovic and Tursko Rudari), as well as by high-sulphidation epithermal Au mineralization styles (as Plavica and Maricanski Rid). The ore mineralization in the Plavica deposit is controlled by steep and sloping faults. The deposit is nominated as a highsulfidation epithermal system, most notably due to the presence of vuggy silica ridges in the deposit and the development of advanced argillic alteration and diatreme breccias. These silica ridges appear as lenses between $100 \mathrm{~m}$ and $650 \mathrm{~m}$ in length and can be followed up to the depth of $400 \mathrm{~m}$, where they pinch out. The northern ridge, eastern ridge and Maricanski Ridge are the three main silica ridges observed in the deposit. The eastern ridge prologues in N-S direction, the northern Plavica Ridge is E-W to SW trending and Maricanski Ridge is roughly
E-W trending ${ }^{1}$. Two mineralogical-geochemical ore zones are clearly defined in the deposit: zone of primary sulfide mineralization and zone of secondary $\mathrm{Au}-\mathrm{Fe}$ manganese oxide mineralization. The second zone has economically significant gold concentrations that have been researched in detail with drilling works and surface excavations. A mining complex is planned to be built to extract the gold by hydrometallurgical processing of the oxide ores. The main objective of this study is to determine the spatial distributions of the chemical elements and $3 \mathrm{D}$ modelling of the geochemical association.

\section{Materials and methods}

The data provided by Genesis Resources Ltd and obtained during the exploration drilling after the 2013 campaign were used to determine the spatial correlations and geochemical associations. Some older data were also used. A total of 72264 samples from 503 drill holes were analyzed for the study of the primary geochemical haloes of the Plavica deposit. The drilling samples were analyzed by ICP analysis.

\footnotetext{
${ }^{1}$ Golder Associates. 2017. Feasibility Study Plavica Gold Project Mac-
} edonia. Report Number 1663041.R01.A0, 603 p. 
The elements that are not typical of the ore-forming process or whose concentrations are mostly below the analysis' detection limits are excluded from the dataset (as B, Ce, Ga, Ge, Hg, In, Nb, Rb, Ta, Te, Th, TI, U). A total of 35 elements were included for the statistical data processing $\mathrm{Au}, \mathrm{Ag}, \mathrm{Al}, \mathrm{As}, \mathrm{Ba}$, $\mathrm{Be}, \mathrm{Bi}, \mathrm{Ca}, \mathrm{Cd}, \mathrm{Co}, \mathrm{Cr}, \mathrm{Cu}, \mathrm{Fe}, \mathrm{K}, \mathrm{La}, \mathrm{Li}, \mathrm{Mg}, \mathrm{Mn}$, Mo, Na, Ni, P, Pb, S, Sb, Sc, Se, Sn, Sr, Ti, V, W, $\mathrm{Y}, \mathrm{Zn}, \mathrm{Zr})$. The methodology of determination of the geochemical associations developed by Popov $(2002,2016)$ is used to evaluate the spatial correlations between the elements and the 3D modelling. The statistical processing was done in Jamovi software and includes as follows: preliminary data preparation and univariate statistical analysis; correlation and cluster analysis; factor analysis and 3D modelling of the geochemical associations. Principal component analysis with Varimax normalized rotation method was the main approach to evaluate the factors representing the geochemical associations. The 3D modelling of spatial distribution of the invoked geochemical associations was processed with the Leapfrog 3D modelling software. Radial Basis Function (RBF) was used to interpolate the scattered data with varying sample density.

\section{Results and discussion}

The results of the factor analysis of 35 elements are presented in Table 1, where the factors are decomposed into 10 axes. Based on the factor analysis, the scores for each sample in the given factor can be calculated (Popov, 2002, 2016). This approach gives the possibility to perform further modelling of the factor scores that represent the spatial relationship between elements (Fig. 1). Ten groups of elements with similar spatial distribution were obtained in the Plavica deposit as a result of the applied methods (Table 1).

As can be seen from Table 1, the first factor takes into account the behavior of the group of ele- ments $\mathrm{Mn}, \mathrm{Mg}, \mathrm{Be}, \mathrm{K}$ and $\mathrm{Zn}$. Although with lower weights, $\mathrm{Ca}$ and $\mathrm{Sc}$ also took part in this group. The high negative weight of $\mathrm{Sr}$ means that this element shows an inverse relationship with the elements in the group. The second factor axis represents the association of elements Sc, Al, Y and V, while Se, Zr, $\mathrm{Mg}$ and $\mathrm{K}$ are joined with less influence here.

The third factor associates $\mathrm{Cr}$ and $\mathrm{P}$, which are very highly correlated $(\mathrm{r}=0.71)$. The elements $\mathrm{Zr}$, $\mathrm{Sr}, \mathrm{Ni}$ and Be also show a tendency to join here with low weights. The fourth factor axis represents the distribution of the main ore elements in the deposit, joined in association of $\mathrm{As}, \mathrm{Sb}, \mathrm{Au}$ and $\mathrm{Sn}$, as well as including $\mathrm{Cu}, \mathrm{Bi}, \mathrm{Fe}$ and $\mathrm{Ag}$ with lower weights. The correlation between $\mathrm{Au}$ and As shows that the form of presence of the gold is mainly as an intermixture in arsenopyrite. The fifth factor reflects the relatively weak correlation between $\mathrm{Ba}$ and $\mathrm{La}$. With negative weights, i.e. with an inversely proportional dependence on these two elements are $\mathrm{S}$, $\mathrm{Co}$ and V. The sixth factor describes the group of $\mathrm{Zn}, \mathrm{Cd}$ and $\mathrm{Pb}$, which probably represents the prevalence of galena-sphalerite association. The seventh factor axis marks an association of $\mathrm{Ni}, \mathrm{W}$ and $\mathrm{Co}$, as some influence here shows $\mathrm{Sn}$ as well. The eighth factor involves the group of $\mathrm{Na}, \mathrm{Ca}$ and $\mathrm{Mg}$, caused by the relatively high correlation between $\mathrm{Ca}$ and $\mathrm{Mg}$ and the weaker relationship between $\mathrm{Na}$ and $\mathrm{Ca}$. The ninth and tenth factors include elements with predominantly independent behavior, as the ninth axis considering the negative correlation between $\mathrm{Li}$ and $\mathrm{K}$, and the tenth axis groups $\mathrm{Fe}$, Mo and $\mathrm{Se}$, which have very low correlations.

As can be seen from Table 1, some elements take part in more than one factor. This suggests a possible wider participation of these elements in the different stages of the ore formation process, as well as their possible presence in more than one mineral paragenesis.

To represent the spatial distribution of geochemical associations, 3D models have been created by

Table 1. Geochemical associations of elements with similar spatial distribution, obtained by factor analysis of the data from the Plavica deposit

\begin{tabular}{|c|c|c|c|}
\hline Factor & Geochemical association & SS loadings & $\%$ of variance \\
\hline Factor 1 & $([\mathrm{Mn}, \mathrm{Mg}, \mathrm{Be}, \mathrm{K}, \mathrm{Zn}] \mathrm{Ca}, \mathrm{Sc}) \quad-[\mathrm{Sr}]$ & 3.27 & 9.35 \\
\hline Factor 2 & $([\mathrm{Sc}, \mathrm{Al}, \mathrm{Y}, \mathrm{V}] \mathrm{Se}, \mathrm{Zr}, \mathrm{Mg}, \mathrm{K})$ & 2.87 & 8.20 \\
\hline Factor 3 & $([\mathrm{Cr}, \mathrm{P}] \mathrm{Zr}, \mathrm{Sr}, \mathrm{Ni}, \mathrm{Be})$ & 2.51 & 7.16 \\
\hline Factor 4 & $([\mathrm{As}, \mathrm{Sb}, \mathrm{Au}, \mathrm{Sn}] \mathrm{Cu}, \mathrm{Bi}, \mathrm{Fe}, \mathrm{Ag})$ & 2.47 & 7.06 \\
\hline Factor 5 & $-([\mathrm{S}] \mathrm{Co}, \mathrm{V})$ & 2.29 & 6.54 \\
\hline Factor 6 & {$[\mathrm{Zn}, \mathrm{Cd}, \mathrm{Pb}]$} & 1.64 & 4.70 \\
\hline Factor 7 & $([\mathrm{Ni}, \mathrm{W}, \mathrm{Co}] \mathrm{Sn})$ & 1.57 & 4.49 \\
\hline Factor 8 & $([\mathrm{Na}, \mathrm{Ca}] \mathrm{Mg})$ & 1.41 & 4.02 \\
\hline Factor 9 & [Li] & 1.38 & 3.95 \\
\hline Factor 10 & $([\mathrm{Fe}, \mathrm{Mo}] \mathrm{Se})$ & 1.27 & 3.62 \\
\hline
\end{tabular}




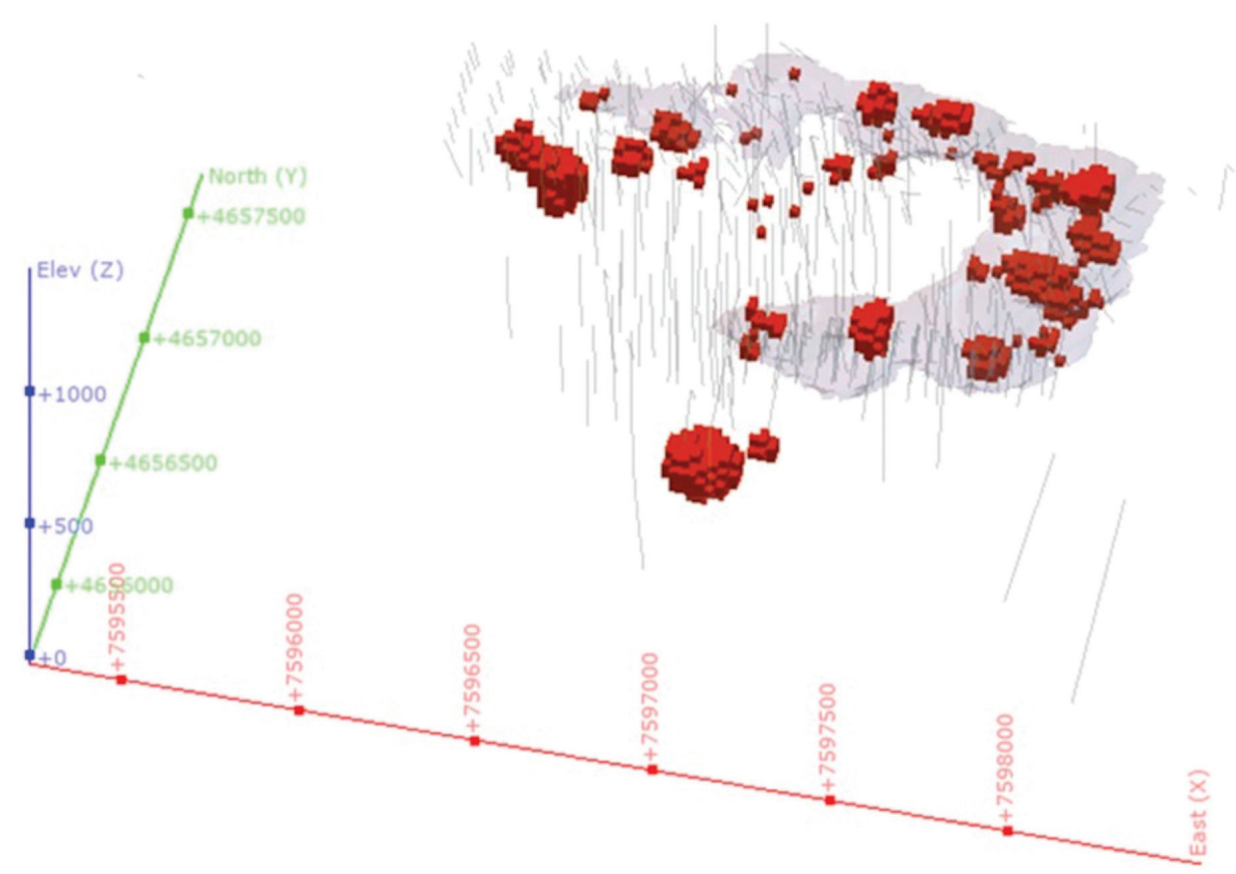

Fig. 1. Distribution of the geochemical association ([As, $\mathrm{Sb}, \mathrm{Au}, \mathrm{Sn}] \mathrm{Cu}, \mathrm{Bi}, \mathrm{Fe}, \mathrm{Ag}$ )

the factor scores of the samples in each factor. For this purpose, the obtained data on the factor weights of the elements were imported in the Leapfrog software, where three-dimensional block models of factors' spreading were compiled by interpolation with the "inverse distance" method. The results of the 3D modeling of the geochemical associations' spatial distributions clearly emphasize the existing zonation in the deposit. The group of elements ([Mn, $\mathrm{Mg}, \mathrm{Be}, \mathrm{K}, \mathrm{Zn}] \mathrm{Ca}, \mathrm{Sc}$ ) is developed mainly in the area between the Plavica and Maricanski Rid peaks, as well as on the periphery of the ore bodies, and probably marks areas with a lower degree of hydrothermal alterations and secondary oxidation. The geochemical associations of ([Sc, Al, Y, V] Se, $\mathrm{Zr}, \mathrm{Mg}, \mathrm{K})$ and $([\mathrm{Cr}, \mathrm{P}] \mathrm{Zr}, \mathrm{Sr}, \mathrm{Ni}, \mathrm{Be}$ ) have also been developed on the periphery and between the ore bodies. The geochemical association of ([As, $\mathrm{Sb}, \mathrm{Au}, \mathrm{Sn}] \mathrm{Cu}, \mathrm{Bi}, \mathrm{Fe}, \mathrm{Ag}$ ) represents the generalized distribution of the main ore elements, outlining the development of the ore bodies (Fig. 1). The correlation between As and $\mathrm{Au}$ reflects that the most probable form of $\mathrm{Au}$ presence is as inclusions in arsenopyrite. The presence here of $\mathrm{Sn}, \mathrm{Sb}$ and $\mathrm{Cu}$ is an indication of their presence in this mineral par- agenesis, probably in the form of minerals from the tetrahedrite-tennantite series.

\section{Conclusion}

The results of the 3D modelling of the factor scores allows to clarify the geochemical associations and spatial distribution of the groups of elements characterized by a certain spatial similarity. The association of ([As, $\mathrm{Sb}, \mathrm{Au}, \mathrm{Sn}] \mathrm{Cu}, \mathrm{Bi}, \mathrm{Fe}, \mathrm{Ag}$ ) represents the distribution of the main ore elements in the deposit. The association of $[\mathrm{Zn}, \mathrm{Cd}, \mathrm{Pb}]$ outlines the distribution of galena-sphalerite association.

Acknowledgements: The authors are grateful to the Seequent Limited which provided academic license of the Leapfrog Geo software for the 3D geological modelling and geostatistical analysis.

\section{References}

Popov, K. 2002. Geochemical association in Radka ore district. - Ann. Univ. Mining and Geol., 45, 1-Geol. and Geophys., 57-63.

Popov, K. 2016. 3D Modelling of the geochemical associations in the Assarel porphyry-copper deposit (Bulgaria). - C. R. Acad. bulg. Sci., 69, 9, 1175-1182. 